Research Article

\title{
Spatial Variations and Potential Risks of Heavy Metals in Seawater, Sediments, and Living Organisms in Jiuzhen Bay, China
}

\author{
Xia Sun, ${ }^{1}$ Bao-Shi Li $\mathbb{D}^{1},{ }^{1}$ Xuan-Li Liu, ${ }^{1}$ and Cheng-Xuan Li $\mathbb{C}^{2,3}$ \\ ${ }^{1}$ Marine Ecology Research Center, The First Institute of Oceanography, Ministry of Natural Resources of China, \\ Qingdao 266061, China \\ ${ }^{2}$ Laboratory for Marine Ecology and Environmental Science, Qingdao National Laboratory for Marine Science and Technology, \\ Qingdao 266237, China \\ ${ }^{3}$ Key Laboratory of Science and Technology of Marine Ecological Environment, The First Institute of Oceanography, \\ Ministry of Natural Resources of China, Qingdao 266061, China
}

Correspondence should be addressed to Cheng-Xuan Li; cxli@fio.org.cn

Received 18 October 2019; Revised 23 December 2019; Accepted 9 January 2020; Published 3 February 2020

Guest Editor: Yuhe He

Copyright (C) 2020 Xia Sun et al. This is an open access article distributed under the Creative Commons Attribution License, which permits unrestricted use, distribution, and reproduction in any medium, provided the original work is properly cited.

Coastal waters are polluted by heavy metals to varying degrees, posing potential risks to marine ecology and human health. In May 2006, the pollution levels, sources, and ecological risks of heavy metals ( $\mathrm{Cu}, \mathrm{Pb}, \mathrm{Zn}, \mathrm{Cd}, \mathrm{Hg}$, and $\mathrm{As}$ ) in seawater, surface sediments, and living organisms were studied in Jiuzhen Bay in Fujian, China. This study identified Hg $(0.26-0.72 \mu \mathrm{g} / \mathrm{L})$ and As $(20.3-31.5 \mu \mathrm{g} / \mathrm{L})$ pollution in the seawater of Jiuzhen Bay. In sediments, heavy Pb pollution $(946 \mu \mathrm{g} / \mathrm{g} \mathrm{dw})$ was only detected at one station at a level posing very serious potential risk, while $\mathrm{Hg}$ pollution $(0.052-0.087 \mu \mathrm{g} / \mathrm{g} \mathrm{dw})$ was observed at three stations at a level posing serious potential risk. No heavy metal pollution was detected in sediments at other stations. The concentrations of five heavy metals $(\mathrm{Cu}, \mathrm{Zn}, \mathrm{As}, \mathrm{Cd}$, and $\mathrm{Pb}$ ) exceeded the corresponding National Quality Standards for oysters, indicating heavy pollution, based on an ecological risk assessment. In clams, two heavy metals ( $\mathrm{Pb}$ and $\mathrm{As}$ ) exceeded the standards, indicating light pollution, based on an ecological risk assessment. No heavy metal pollution was found in fish or shrimps. The heavy metals in the seawater and sediments of Jiuzhen Bay are mainly derived from the river discharges of Luxi and Wujiang Rivers although sewage discharge along the coast of Jiuzhen Bay is another source of heavy metal pollution at some stations. Given the pollution of $\mathrm{Pb}, \mathrm{Hg}$, and $\mathrm{As}$ in seawater and sediments at some stations within the bay, the potential risks of $\mathrm{Pb}, \mathrm{Hg}$, and As in living organisms to both the marine ecology and human health deserve increased attention.

\section{Introduction}

Over the past 40 years, because of rapid industrialization and economic development in China, the problem of soil contamination by heavy metals has become increasingly serious [1], with large amounts of these soil pollutants being discharged into coastal and estuarine environments by rivers and other pathways $[2,3]$. Compared with other pollutants, heavy metals are persistent and have toxic as well as bioaccumulation effects, which severely damage marine environments [4]. Therefore, heavy metal contamination has attracted much attention and become the focus of global concern in recent years. Estuaries and coastal regions (such as bays) are important components of coastal systems, receiving large amounts of heavy metals via riverine input [5-7].

Estuaries are zone of complex interaction between fluvial and marine ecosystems in which many critical environmental processes including sediment deposition, fresh water-salt water interaction, delta accretion, pollutant retention, and material-energy exchanges occur. Particularly, the mixing of continental river water and marine salt water usually leads to flocculation and accumulation processes of heavy metals [8]. Although metal-aquo chemistry is the main factor affecting the removal and transformation of heavy metals, sediment type also has a major effect on transport and accumulation of heavy metals. Therefore, the spatial patterns of heavy metals are 
closely related to sediment types [9]. The spatial distributions of heavy metals are often consistent with those of fine-grained sediments [10]. Most heavy metals become part of the sediment through different biogeochemical processes, which trigger precipitation and deposition [11]. Heavy metals do not behave conservatively, and they are also affected by changing physicochemical conditions, such as salinity, $\mathrm{pH}$, and redox conditions [12]. When sedimentary environments change, the heavy metals in the sediment may be released back into the water body through various processes of remobilization, producing secondary pollution within the environment [13]. Therefore, marine sediments are considered an important sink of heavy metals, especially in coastal areas.

Heavy metals in seawater and marine sediments can be directly absorbed by organisms and then accumulated and transformed within their bodies. Accumulation may be magnified via the food chain, thereby threatening the marine ecosystem and human health [14-16]. Zhao et al. [17] reported that some seafood from Xiangshan Bay might pose noncarcinogenic risks to both adults and children. Although consumption of most common types of seafood from Xiamen markets does not pose a noncarcinogenic risk, some types, such as yellowfin bream (Sparus latus), oyster, and the Red alga (nori; Porphyra tenera), could form a carcinogenic risk [18]. The levels of five metals in marine fish and shellfish from China are generally low, based on published data. However, some findings suggest that there are health risks from exposure to $\mathrm{Cd}$ and As in some shellfish [19]. Considering the pollution of heavy metals in seawater and sediments in coastal areas, the risk of heavy metal pollution in seafood deserves greater attention.

Jiuzhen Bay is located on the southern coast of Fujian, between Gulei and Liu'ao Peninsulas. It is a concave, semienclosed shallow bay, forming an estuary. Its coastline is $45.97 \mathrm{~km}$ in length, with a total embayed area of $69.64 \mathrm{~km}^{2}$. The entire bay is occupied by an intertidal shoal, except for its tidal channel. The intertidal area accounts for about $80 \%$ of the bay area. The tidal inlet runs from the bay's mouth to the Luxi River outlet [20]. Jiuzhen Bay has rich marine biological resources and is an important marine aquaculture base in Fujian. The main aquaculture species are shellfish. Along the coast of Jiuzhen Bay, there are multiple industries, such as wind power generation, shipbuilding, placer mining, seafood processing, and shipping. In addition, the nearby Gulei Port Economic Development Zone is one of the seven petrochemical bases in China. The pollutant discharges from these various industrial enterprises may be causing serious environmental impacts on Jiuzhen Bay.

Given the environmental and sedimentation characteristics of Jiuzhen Bay, most of the heavy metals entering Jiuzhen Bay accumulate within the bay. To date, there has been no research on the distribution and ecological risk of heavy metals in seawater, sediments, or seafood of Jiuzhen Bay. The purpose of this study was to (1) determine the contents and distributions of various heavy metals in seawater, sediments, and living organisms within the bay; (2) analyze the sources of these heavy metals; and (3) evaluate the degree of heavy metal pollution, using the single-factor pollution index, comprehensive index evaluation, and potential ecological risk index.

The data provided here will assist the local government to monitor the change in the heavy metal pollution status of this area and implement targeted control measures.

\section{Materials and Methods}

2.1. Sample Collection. A total of nine stations were investigated during the survey of May 2006, as shown in Figure 1. A GO-FLO water sampler (General Oceanics, Inc., Miami, FL, USA) was used for sample collection. Water only within the surface layer was collected at stations, where water depths were less than $5 \mathrm{~m}$ (A1, B1, and B2), while water samples from surface (Sur) and bottom (Bot) layers were collected at stations with water depths of 5-20 m (B3, C1, C2, and E1-E3). Water samples were preserved at $-20^{\circ} \mathrm{C}$ for later analysis. Sediment samples were collected using a grab bucket-type bottom sampler; sediments from the $0-2 \mathrm{~cm}$ surface layer were placed in a polyethylene sealing bag and preserved at $-20^{\circ} \mathrm{C}$ for later analysis.

Biological samples were collected by trawling, and strict criteria were used to select adults of local representative biological species for the study. Specimens were preserved at $-20^{\circ} \mathrm{C}$ for later analysis.

2.2. Laboratory Analysis. Six heavy metals- $\mathrm{Cu}, \mathrm{Pb}, \mathrm{Zn}, \mathrm{Cd}$, $\mathrm{Hg}$, and As-in seawater, sediments, and living organisms were analyzed in this study.

All water samples were filtered using a hybrid cellulose ester Millipore filter, which was dipped before filtering in acid. The filtrate was acidified to $\mathrm{pH}<2$ with $\mathrm{HNO}_{3}$ and stored in a Teflon bottle.

Before analysis of the sediment samples, they were freeze-dried. All large debris was removed, followed by grinding and sieving. Dry sediment samples were dissolved in an equimolar mixture of $\mathrm{HF}, \mathrm{HNO}_{3}$, and $\mathrm{HClO}_{4}$, having a volumetric ratio of $3: 1: 0.5$, and then evaporated to dryness. The samples were redissolved with aqua regia, and three parts of this metal solution were diluted with $\mathrm{HNO}_{3}$.

Edible parts of living organisms were removed using biomedical stainless-steel implements, smashed using a stamping machine, blended, and dried in an oven, allowing moisture content to be calculated. Dried biological samples were digested like sediments.

$\mathrm{Cu}, \mathrm{Pb}, \mathrm{Zn}$, and $\mathrm{Cd}$ were analyzed using an Agilent 7500a inductively coupled plasma source mass spectrometer (Agilent Technologies, Inc., Santa Clara, CA, USA), while Hg and As were analyzed using an atomic fluorescent photometer AFS200T (Skyray Instrument, Inc., Stoughton, MA, USA).

Total nitrogen (TN), total phosphorus (TP), dissolved inorganic nitrogen (DIN), dissolved inorganic silicon (DSi), and $\mathrm{PO}_{4}$ were measured using a spectrophotometric method, while total organic carbon (TOC), redox potential (Eh), and $\mathrm{pH}$ were analyzed using $\mathrm{K}_{2} \mathrm{Cr}_{2} \mathrm{O}_{7}$ oxidation-reduction volumetric method and potentiometer and acid meter method, respectively. DIN is the sum of $\mathrm{NO}_{3}{ }^{-}, \mathrm{NO}_{2}{ }^{-}$, 


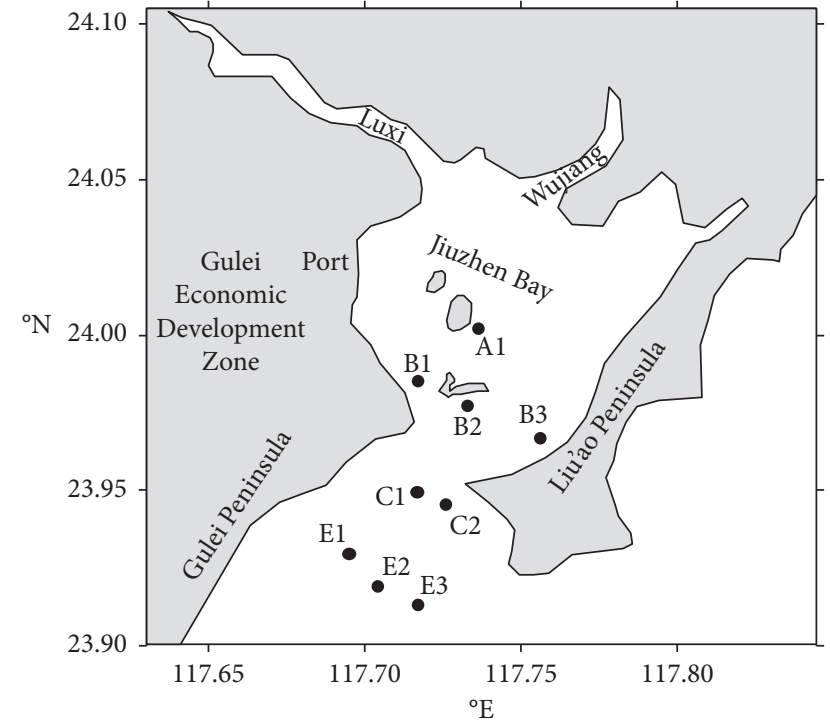

FIGURE 1: Location of the Jiuzhen Bay study area and all sampling stations.

and $\mathrm{NH}_{4}{ }^{+}$. TN, TP, DIN, DSi, and $\mathrm{PO}_{4}$ were analyzed using a flow injection analyzer (model: Lachat-QC8000). Redox potential (Eh) and $\mathrm{pH}$ were determined using an acid meter (model: pHS-3C).

2.3. Quality Control and Quality Assurance. Laboratory quality assurance and quality control methods were practiced, involving standard operating procedures, calibration using standards, and analysis of reagent blanks. All samples were analyzed in parallel at proportions of 10\%. Quality control was ensured by measuring nationally certified standard reference materials (GBW07314, GBW080042, GBW080230, GBW080040, and GBW 10050). The differences in the concentrations between the certified and measured values were $<5 \%$. The recoveries of all metals were within the range of $85 \%-99 \%$. The relative measurement error was less than $10 \%$.

2.4. Data Analysis and Evaluation Methods. Pearson correlation analysis was used to quantify relationships among heavy metals. Data calculation and statistics were performed with SPSS 17.0 statistical software (IBM, Armonk, NY, USA) and Microsoft Excel (Microsoft Corp., Albuquerque, NM, USA). The figures in this paper were drawn with Surfer 8 (Scientific Software Group, Salt Lake City, UT, USA).

The single-factor index method was used to evaluate heavy metals in seawater, using the formula below:

$$
P_{i}=C_{i} \times S_{i j}
$$

where $P_{i}$ is the heavy metal pollution index, $C_{i}$ is the concentration value of a given heavy metal, and $S_{i j}$ is the standard value of a given heavy metal. The Type I Standard of the National Seawater Quality Standard (China) was used to obtain standard values of heavy metals in seawater, yielding values for $\mathrm{Cu}(5 \mu \mathrm{g} / \mathrm{L}), \mathrm{Zn}(20 \mu \mathrm{g} / \mathrm{L})$, As $(20 \mu \mathrm{g} / \mathrm{L}), \mathrm{Cd}(1 \mu \mathrm{g} /$ $\mathrm{L}), \mathrm{Hg}(0.05 \mu \mathrm{g} / \mathrm{L})$, and $\mathrm{Pb}(1 \mu \mathrm{g} / \mathrm{L})$.

Biotoxicity or biological risks of heavy metals in sediments were evaluated using the potential ecological risk index proposed by the Swedish scholar Hakanson [21], using the formula below:

$$
\begin{aligned}
& E_{r}^{i}=T_{r}^{i} \times C_{r}^{i}=T_{r}^{i} \times \frac{C_{i}}{C_{n}^{i}}, \\
& R I=\sum_{i=1}^{n} E_{r}^{i},
\end{aligned}
$$

where $T_{r}^{i}$ is the toxicity response coefficient of a heavy metal and those of $\mathrm{Hg}, \mathrm{Cd}, \mathrm{As}, \mathrm{Cu}, \mathrm{Pb}$, and $\mathrm{Zn}$ are, respectively, set as $40,30,10,5,5$, and $1[22,23] ; C_{r}^{i}$ is the pollution index of a given heavy metal, also called its enrichment coefficient; $C_{i}$ is the measured concentration of the given heavy metal in sediments; $C_{n}^{i}$ is the background value of the given heavy metal; $E_{r}^{i}$ is the potential ecological risk index of the given heavy metal; and $R I$ is the total potential ecological risk index related to multiple heavy metals. The degrees of ecological risk corresponding to $E_{r}^{i}$ and $R I$ values are given in Table 1 .

The single-factor evaluation method and comprehensive index evaluation method were combined to evaluate heavy metals in living organisms. In this case, the National Quality Standard was a bivalve, referred to as the Type I Standard in Marine Biological Quality (China) (GB18421-2001). Standard values for crustacea and fish are taken from previously determined values from monitoring and evaluation of heavy metal pollution elements in offshore areas [24].

The formula for the comprehensive index evaluation method is given below:

$$
P_{i j}=\sqrt{\frac{\left(\max P_{i}\right)^{2}+\left(\operatorname{ave} P_{i}\right)^{2}}{2}},
$$

where $P_{i j}$ is the comprehensive quality index, $P_{i}$ is the singlefactor pollution index, $\max P_{i}$ is the maximum value of the single-factor pollution index for a given living organism, and ave $P_{i}$ is the average value of the single-factor pollution index of a given living organism.

The degree of heavy metal pollution in marine living organisms that correspond to values obtained from the comprehensive index method are given in Table 2 .

In this paper, the bioconcentration factors (BCFs) and biota-sediment accumulation factors (BSAFs) were calculated to analyze the bioaccumulation of heavy metals from seawater and sediments in living organisms. The BCFs indicate the status of organisms enriched in heavy metals from the surrounding waters, while the BSAFs evaluate the equilibrium relationship of heavy metal contents in benthic organisms and sediments, i.e., the indirect absorption of heavy metals by benthic organisms from their living environments $[25,26]$.

The calculations are defined as follows: 
TABLE 1: Degrees of potential risks corresponding to various values of the potential risk index $\left(E_{r}^{i}\right)$ and total potential ecological risk index $(R I)$.

\begin{tabular}{lcc}
\hline $\begin{array}{l}\text { Range of potential } \\
\text { ecological risk index } \\
\begin{array}{l}E_{r}^{i} \text { of a single heavy } \\
\text { metal }\end{array}\end{array}$ & $\begin{array}{c}\text { Range of total potential } \\
\text { comprehensive } \\
\text { ecological risk index } R I\end{array}$ & $\begin{array}{c}\text { Degree of } \\
\text { potential } \\
\text { ecological risk }\end{array}$ \\
\hline$E_{r}^{i}<40$ & $R I<150$ & $\begin{array}{c}\text { Low potential } \\
\text { ecological risk }\end{array}$ \\
\hline $40 \leq E_{r}^{i}<80$ & $150 \leq R I<300$ & $\begin{array}{c}\text { Moderate } \\
\text { potential } \\
\text { ecological risk }\end{array}$ \\
\hline $80 \leq E_{r}^{i}<160$ & $300<R I<600$ & $\begin{array}{c}\text { Relatively } \\
\text { severe potential } \\
\text { ecological risk }\end{array}$ \\
\hline $160 \leq E_{r}^{i}<20$ & $R I \geq 600$ & $\begin{array}{c}\text { Severe potential } \\
\text { ecological risk }\end{array}$ \\
\hline$E_{r}^{i} \geq 320$ & - & $\begin{array}{c}\text { Very heavy } \\
\text { potential }\end{array}$ \\
\hline
\end{tabular}

TABLE 2: Grades for the comprehensive quality index $\left(P_{i j}\right)$ evaluation of heavy metals in marine living organisms.

\begin{tabular}{lcc}
\hline Grade & Comprehensive quality index, $P_{i j}$ & Pollution degree \\
\hline Grade I & $P_{i j}>3$ & Heavy pollution \\
Grade II & $2<P_{i j} \leq 3$ & Medium pollution \\
Grade III & $1<P_{i j} \leq 2$ & Light pollution \\
Grade IV & $P_{i j} \leq 1$ & No pollution \\
\hline
\end{tabular}

$$
\begin{gathered}
\text { BCF }=\frac{C_{x}}{C_{s w}}, \\
\text { BSAF }=\frac{C_{x}}{C_{s}},
\end{gathered}
$$

where $C_{x}$ and $C_{\mathrm{sw}}$ are the mean concentrations of a given metal in the organism and in seawater, respectively, while $C_{\mathrm{s}}$ is the mean concentration of the metal in the sediment.

\section{Results and Discussion}

\subsection{Distribution Characteristics and Evaluation of Heavy Metal Pollution in Seawater}

3.1.1. Distribution Characteristics of Heavy Metals in Seawater. Heavy metal contents in seawater were measured in samples from all stations within Jiuzhen Bay, as shown in Table 3. Analysis of their vertical distributions show that the average values of heavy metals- $\mathrm{Cd}$ and $\mathrm{Pb}$-in seawater from the surface layer were higher than those in the bottom layer, while other heavy metal contents $(\mathrm{Cu}, \mathrm{Zn}, \mathrm{As}$, and $\mathrm{Hg}$ ) in the surface layer were lower than those in the bottom layer. $\mathrm{Zn}$ concentrations in the bottom layer were twice those in the surface layer.

The overall horizontal distribution characteristics were as follows. The distribution of heavy metals $(\mathrm{Cu}, \mathrm{As}$, and $\mathrm{Hg}$ ) in the surface and bottom seawater layers were relatively consistent, both layers showing a decrease from the outer to inner parts of the bay, with highest values within the bay's mouth and outer areas. There was a distinct difference in the distribution of $\mathrm{Pb}$ in the surface and bottom seawater layers. An area having a low $\mathrm{Pb}$ content occurred on the inner side of the mouth. The $\mathrm{Pb}$ content gradually increased in surrounding areas, resulting in a high value at station $\mathrm{B} 1$ on the west side of the bay. In the bottom seawater layer, high levels of $\mathrm{Pb}$ were detected at stations $\mathrm{B} 3$ and $\mathrm{C} 2$, while $\mathrm{Pb}$ gradually decreased from east to west. An overall decrease from the bay's mouth to outer areas was observed for $\mathrm{Cd}$ in both the surface and bottom seawater layers, with the highest values within the mouth area. The distribution of $\mathrm{Zn}$ varied greatly in the surface and bottom seawater layers. Although $\mathrm{Zn}$ displayed a consistent trend, like those of $\mathrm{Cu}, \mathrm{As}$, and $\mathrm{Hg}$ in surface seawater, its concentration at station C2 in the bottom seawater layer was $123 \mu \mathrm{g} / \mathrm{L}$, which was seven times that of surrounding stations. Distributions of all six heavy metals within Jiuzhen Bay are shown in Figure 2.

The contents of heavy metals in seawater measured in the present study were compared with historical data and studies of other regions in China (Table 4). In comparison with historical data [20], the contents of $\mathrm{Cu}$ and $\mathrm{Cd}$ have increased markedly. Except for the much higher contents of $\mathrm{Hg}$ and As, the heavy metal contents determined in the present study were basically consistent with those of the southern Gulf of China [13, 17, 27-29]. This comparison indicates that heavy metal content of the seawater of Jiaozhou Bay was the highest among all documented bays [30].

3.1.2. Main Factors Affecting Dissolved Heavy Metal Distributions in Seawater. According to the correlation analysis between the heavy metals in seawater and environmental factors (Table 5), significant correlations were determined between heavy metals ( $\mathrm{As}, \mathrm{Hg}$, and $\mathrm{Cu}$ ) and environmental factors $\left(\mathrm{PO}_{4}, \mathrm{Si}\right.$, and $\left.\mathrm{DIN}\right)(R>0.605, P<0.05, N=15)$, indicating certain similar sources of the substances. In fact, the sources of heavy metals $(\mathrm{As}, \mathrm{Hg}$, and $\mathrm{Cu}$ ) in seawater are indeed similar to those of $\mathrm{PO}_{4}, \mathrm{Si}$, and $\mathrm{DIN}$, mainly being river water and domestic and industrial wastewater along the coast of Jiuzhen Bay. The distribution trend of heavy metals (As, $\mathrm{Hg}$, and $\mathrm{Cu}$ ) increased gradually from the mouth of the bay out to sea. The higher concentrations at the mouth were results from the changes in environmental factors such as salinity and redox factors. Specifically, the heavy metals adsorbed by suspended particles in the river water dissolved out, resulting in high contents of $\mathrm{As}, \mathrm{Hg}$, and $\mathrm{Cu}$ in the seawater at the mouth. This is consistent with the conclusions of Zhang et al. [31], in which study it was proposed that the content of heavy metals in the downstream of the Yellow River was lower than that at the estuary, and the content of dissolved heavy metals was closely related to the adsorption and desorption of heavy metals in suspended particles.

In the seawater of bays and estuaries, heavy metal content is affected by changes in environmental factors such as salinity, hydrodynamics, $\mathrm{pH}$, redox, and biological effects $[32,33]$. The investigation sea area is located at the mouth of 
TABLe 3: Heavy metal contents in seawater layers of Jiuzhen Bay $(\mu \mathrm{g} / \mathrm{L})$.

\begin{tabular}{lccc}
\hline Heavy metal type & Total average value (range) & Average value at the surface layer (range) & Average value at the bottom layer (range) \\
\hline $\mathrm{Cu}$ & $4.82(3.37 \sim 6.33)$ & $4.74(3.37 \sim 5.88)$ & $4.94(4.05 \sim 6.33)$ \\
$\mathrm{Zn}$ & $22.0(8.9 \sim 123)$ & $16.7(11.5 \sim 29.2)$ & $30.1(8.9 \sim 123)$ \\
$\mathrm{As}$ & $27.0(20.3 \sim 31.5)$ & $26.3(20.3 \sim 29.8)$ & $27.9(25.0 \sim 31.5)$ \\
$\mathrm{Cd}$ & $0.34(0.24 \sim 0.50)$ & $0.34(0.24 \sim 0.50)$ & $0.32(0.29 \sim 0.35)$ \\
$\mathrm{Hg}$ & $0.46(0.26 \sim 0.72)$ & $0.44(0.26 \sim 0.72)$ & $0.50(0.39 \sim 0.67)$ \\
$\mathrm{Pb}$ & $0.37(0.25 \sim 0.54)$ & $0.37(0.25 \sim 0.45)$ & $0.36(0.25 \sim 0.54)$ \\
\hline
\end{tabular}

Jiuzhen bay, which is the mixing region of river water and seawater. Therefore, the environmental factors vary significantly, posing different degrees of impact on different heavy metals, which is the main reason for the poor correlation between heavy metals and environmental factors.

The maximum value of $\mathrm{Pb}$ content in surface seawater was located at station B1 of shallow water, which is consistent with the location of the high-value zone in the sediment, indicating that the concentration of $\mathrm{Pb}$ in seawater at station B1 was affected by the content of sediment. Upon changes of environmental conditions, the equilibrium between the overlying water and the sediment is broken, resulting in the migration of heavy metal pollutants from the sediment to the water body [12]. The high value area of $\mathrm{Pb}$ in bottom seawater was at the east side of the tidal channel, i.e., the Liu'ao Peninsula and the Liu'ao Port. The population on the Liu'ao Peninsula is mainly concentrated in Liu'ao Town. Large amount of sewage discharge from human domestic and industrial activities to the Jiuzhen Bay resulted in the high $\mathrm{Pb}$ content on the east side of the tidal channel. The maximum concentration of $\mathrm{Zn}$ detected at the $\mathrm{C} 2$ station in bottom seawater was also caused by the discharge of domestic and industrial sewage from Liu'ao Town.

The heavy metals in the seawater of the investigation area are mainly originated from the water of Luxi and Wujiang River, as well as the domestic and industrial wastewater along the coast of the Jiuzhen Bay. Moreover, the dissolution of heavy metals from sediments is another source of heavy metals in seawater.

\subsubsection{Evaluation of Heavy Metal Pollution in Seawater.} Values of the single-factor pollution indices of various heavy metals at each station are given in Table 6, and their respective ranges were $\mathrm{Cu}(0.67-1.27), \mathrm{Zn}(0.45-6.13)$, As (1.02-1.58), Cd (0.24-0.50), $\mathrm{Hg}$ (5.29-14.33), and $\mathrm{Pb}$ (0.25-0.54). Typically, the single-factor pollution indices for both $\mathrm{Hg}$ and $\mathrm{As}$ in Jiuzhen Bay were greater than 1, indicating that both metals exceeded the Type I National Seawater Quality Standard at all stations. $\mathrm{Cu}$ and $\mathrm{Zn}$ exceeded the type I standard at some stations, at rates of $33 \%$ and $13 \%$, respectively. Neither $\mathrm{Cd}$ or $\mathrm{Pb}$ exceeded the type I threshold. According to average values of single-factor pollution indices for heavy metals, their pollution degree was $\mathrm{Hg}>\mathrm{As}>\mathrm{Zn}>\mathrm{Cu}>\mathrm{Pb}>\mathrm{Cd}$.

\subsection{Distribution Characteristics and Evaluation of Heavy Metal Pollution in Sediments}

3.2.1. Distribution Characteristics of Heavy Metals in Sediments. Average heavy metal contents of sediments within Jiuzhen Bay are given in Table $7 . \mathrm{Pb}$ had highest values in sediments along the northern coast and in the northwest part of the mouth of the bay; they progressively declined eastward. A high value area of all five heavy metals $(\mathrm{Cu}, \mathrm{Zn}, \mathrm{Cd}, \mathrm{Hg}$, and $\mathrm{As}$ ) occurred on the northeast side of Jiuzhen Bay. Heavy metal distributions in sediments are shown in Figure 3.

The heavy metal contents in sediments measured in this present study were compared with historical data and studies of other regions (Table 8). Compared with historical data [20], $\mathrm{Pb}$ contents have increased markedly, while other heavy metal contents have remained unchanged. In this paper, the heavy metal contents in sediments were lower than those of other marine areas and bays in China $[10,17,28,36,37]$, except for $\mathrm{Pb}$ content, which was much higher than in all other locations.

\subsubsection{Main Factors Affecting Heavy Metal Distributions in} Sediments. According to our correlation analysis of heavy metals and environmental factors in the sediments (Table 9), a significant positive correlation was determined for $\mathrm{Cu}, \mathrm{Zn}$, $\mathrm{Cd}, \mathrm{Hg}$, and As $(R>0.737 ; P<0.05, N=9)$. This suggests these metals have the same mode of accumulation in surface sediments of Jiuzhen Bay. The main source of these heavy metals was land-based pollution. Regarding the effect of environmental factors, the correlation coefficients for total organic carbon (TOC), TP, total nitrogen (TN), and redox potential (Eh) with $\mathrm{Cu}, \mathrm{Zn}, \mathrm{Cd}, \mathrm{Hg}$, and As were all relatively high, showing strong correlations. The reproduction of plankton removes nutrients from fresh water inputs, forming a large amount of organic suspended matter, just like the natural large-scale ecological beds resulting from sewage treatment in Jiuzhen Bay [38]. The heavy metals combine with organic matter and remain suspended in water mixing zones water, before being precipitated. This may be the cause for the high value areas of all five heavy metals $(\mathrm{Cu}, \mathrm{Zn}, \mathrm{Cd}, \mathrm{Hg}$, and $\mathrm{As})$ on both sides of the tidal channel, as well as the higher contents of heavy metals in sediments within the mouth area, compared with further offshore.

Based on a comparison of historical background values [20], the values of $\mathrm{Pb}$ in sediments were far higher than those of other heavy metals. In terms of their distributions, the correlations of $\mathrm{Pb}$ with other heavy metal elements were nonsignificant. For example, the $\mathrm{Pb}$ content at station $\mathrm{B} 1$ was tens of times more than those at other stations with serious pollution, indicating that increasing $\mathrm{Pb}$ content was related to pollution discharge from land areas on the west side of the bay. 


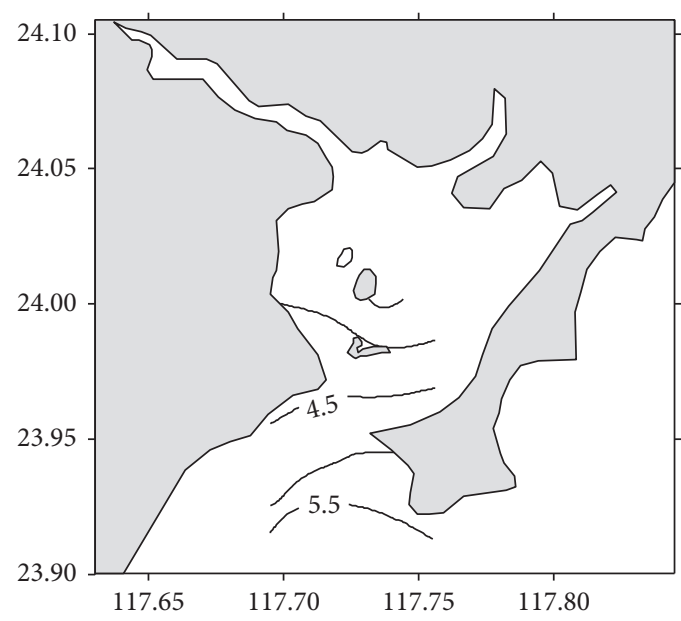

(a)

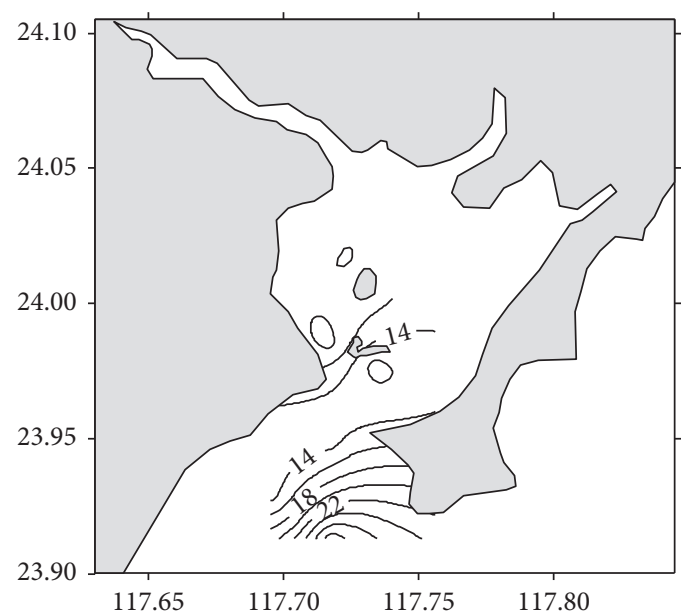

(c)

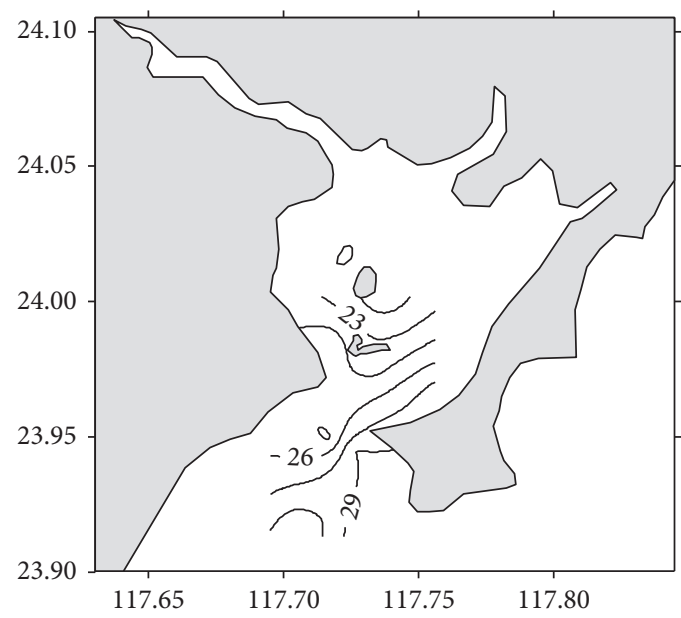

(e)

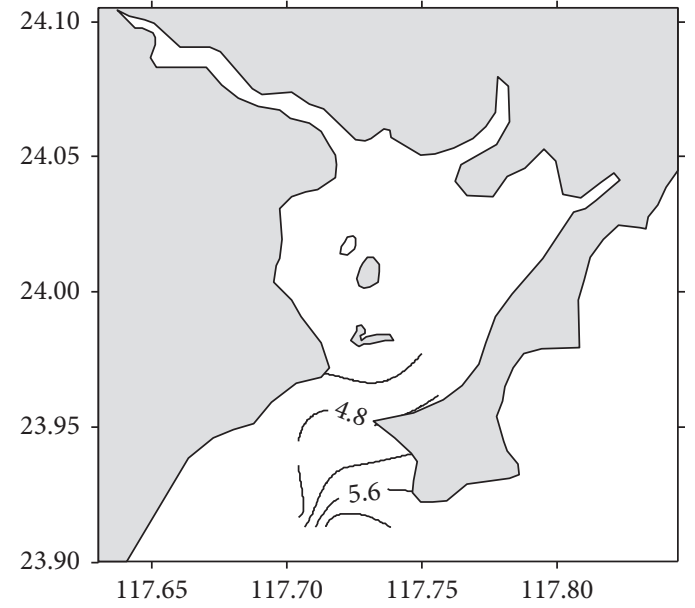

(b)

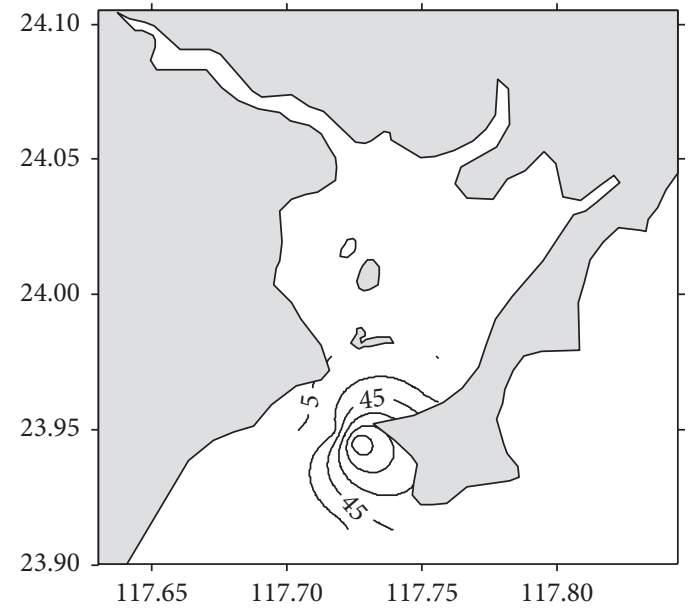

(d)

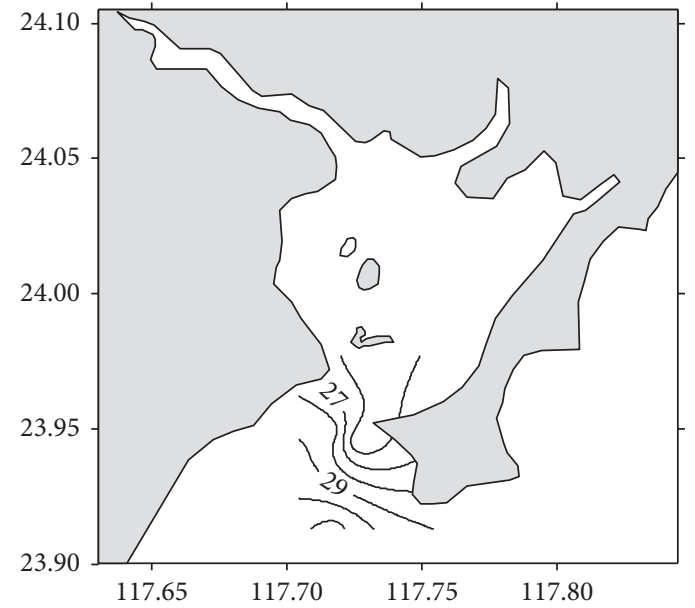

(f)

FIgUre 2: Continued. 


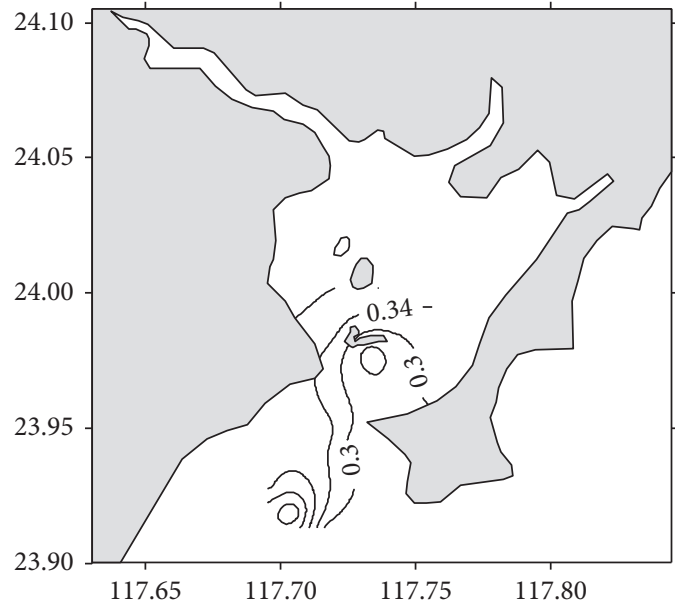

(g)

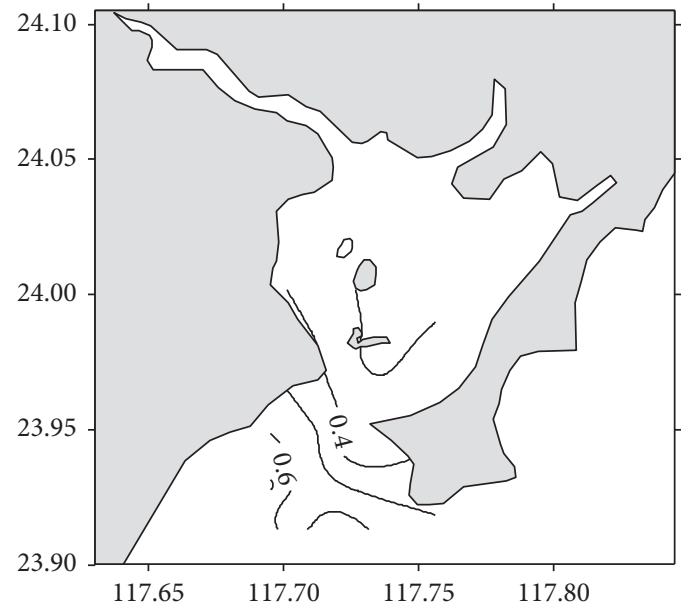

(i)

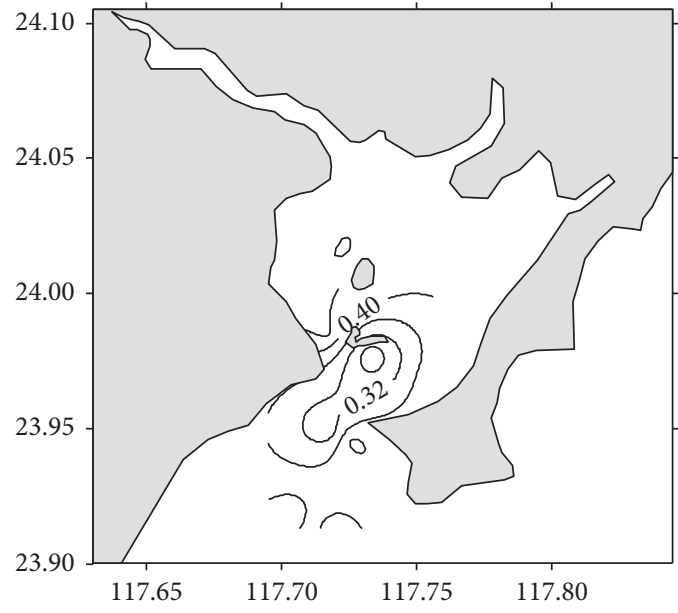

(k)

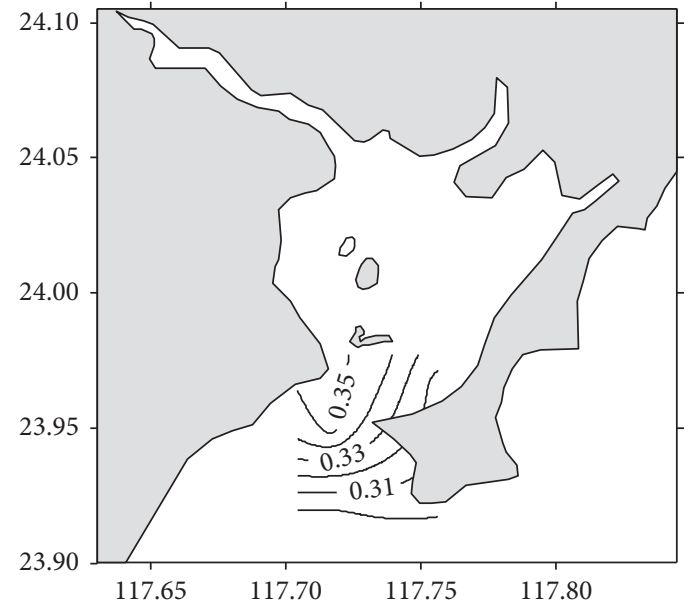

(h)

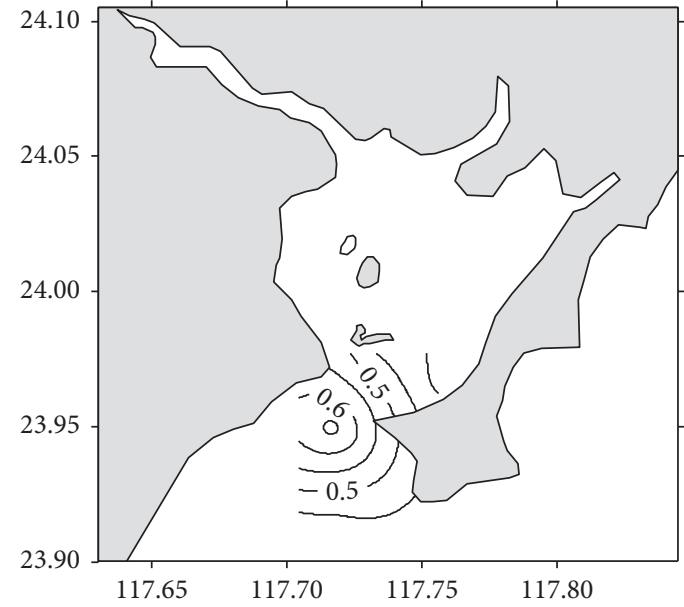

(j)

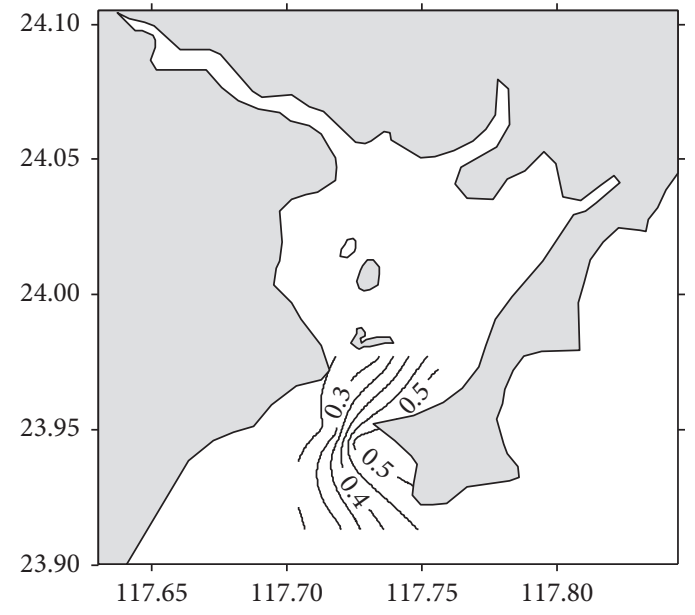

(1)

FIgURe 2: Distributions (surface layer, left panels; bottom layer, right panels) of various heavy metals in the seawater of Jiuzhen Bay ( $\mu$ g/L): (a) Cu Sur; (b) Cu Bot; (c) Zn Sur; (d) Zn Bot; (e) As Sur; (f) As bot; (g) Cd Sur; (h) Cd Bot; (i) Hg Sur; (j) Hg Bot; (k) Pb Sur; (l) Pb Bot.

The contents of $\mathrm{Hg}$ and As in the sediments at Futou Bay are higher than those at Jiuzhen Bay [36], related to the polluted discharge from Gulei Peninsula. Evaluation of the seawater and sediments in Jiuzhen Bay shows that $\mathrm{Hg}$ pollution was heavier than other heavy metals, suggesting that Futou Bay may be another source of Hg. 
TABLE 4: Concentrations of heavy metals in seawater $(\mu \mathrm{g} / \mathrm{l})$ in the present study compared to published data for other locations in China.

\begin{tabular}{lccccccc}
\hline Region & $\mathrm{Cu}$ & $\mathrm{Pb}$ & $\mathrm{Zn}$ & $\mathrm{Cd}$ & $\mathrm{Hg}$ & As & Reference \\
\hline Dongshan Bay, China & 1.21 & 1.66 & 11.1 & 0.032 & - & - & {$[13]$} \\
Xiangshan Bay, China & 4.5 & 2.23 & 16.8 & 0.14 & 0.061 & 2.6 & {$[17]$} \\
East of Qinzhou Bay, China & 0.63 & - & 8.4 & 428 & 0.0205 & 0.845 & {$[27]$} \\
Maowei Sea, China & 5.6 & 2.7 & 48.4 & 0.38 & 0.068 & 0.42 & {$[28]$} \\
Bihe Bay, China & 2.76 & 0.655 & 13.14 & 0.088 & 0.036 & 0.57 & {$[29]$} \\
Jiaozhou Bay, China & 2108.02 & 75.74 & 85.28 & 2.93 & 1.55 & 52.61 & {$[30]$} \\
Data of history & 0.40 & 0.33 & & 0.028 & & & \\
Study area & 4.82 & 0.37 & 22.0 & 0.34 & 0.46 & 27.0 & {$[20]$} \\
\hline
\end{tabular}

TABLE 5: Matrix chart of correlation coefficients among the heavy metals in the seawater.

\begin{tabular}{|c|c|c|c|c|c|c|c|c|c|}
\hline & As & $\mathrm{Hg}$ & $\mathrm{Cu}$ & $\mathrm{Pb}$ & $\mathrm{Cd}$ & $\mathrm{Zn}$ & $\mathrm{PO}_{4}$ & DSi & DIN \\
\hline As & 1 & & & & & & & & \\
\hline $\mathrm{Hg}$ & 0.364 & 1 & & & & & & & \\
\hline $\mathrm{Cu}$ & $0.812^{\mathrm{a}}$ & 0.464 & 1 & & & & & & \\
\hline $\mathrm{Pb}$ & -0.176 & -0.040 & -0.080 & 1 & & & & & \\
\hline $\mathrm{Cd}$ & -0.045 & 0.218 & 0.059 & 0.324 & 1 & & & & \\
\hline $\mathrm{Zn}$ & -0.153 & 0.315 & 0.076 & 0.485 & 0.033 & 1 & & & \\
\hline $\mathrm{PO}_{4}$ & $-0.755^{\mathrm{a}}$ & $-0.734^{\mathrm{a}}$ & $-0.605^{\mathrm{b}}$ & 0.078 & -0.129 & -0.108 & 1 & & \\
\hline $\mathrm{Si}$ & $-0.834^{\mathrm{a}}$ & $-0.634^{b}$ & $-0.689^{\mathrm{a}}$ & 0.024 & 0.080 & -0.187 & $0.918^{\mathrm{a}}$ & 1 & \\
\hline DIN & $-0.813^{\mathrm{a}}$ & $-0.667^{\mathrm{a}}$ & $-0.665^{\mathrm{a}}$ & -0.004 & 0.016 & -0.194 & $0.943^{\mathrm{a}}$ & $0.985^{\mathrm{a}}$ & 1 \\
\hline
\end{tabular}

${ }^{\mathrm{a}}$ Correlation is significant at the 0.01 level. ${ }^{\mathrm{b}}$ Correlation is significant at the 0.05 level.

TABLE 6: Single-factor pollution indices for heavy metals in seawater at all stations of Jiuzhen Bay.

\begin{tabular}{lccccccc}
\hline Station & Layer & $\mathrm{Cu}$ & $\mathrm{Zn}$ & $\mathrm{As}$ & $\mathrm{Cd}$ & $\mathrm{Hg}$ & $\mathrm{Pb}$ \\
\hline $\mathrm{A} 1$ & Sur & 0.67 & 0.82 & 1.02 & 0.38 & 5.29 & 0.42 \\
$\mathrm{~B} 1$ & Sur & 0.87 & 0.93 & 1.27 & 0.36 & 7.52 & 0.45 \\
$\mathrm{~B} 2$ & Sur & 0.84 & 0.57 & 1.18 & 0.24 & 5.43 & 0.25 \\
$\mathrm{~B} 2$ & Bot & 0.81 & 0.54 & 1.25 & 0.35 & 9.01 & 0.29 \\
$\mathrm{~B} 3$ & Sur & 0.91 & 0.65 & 1.41 & 0.32 & 7.59 & 0.40 \\
$\mathrm{~B} 3$ & Bot & 0.94 & 0.45 & 1.35 & 0.32 & 7.71 & 0.54 \\
$\mathrm{C} 1$ & Sur & 0.94 & 0.65 & 1.22 & 0.36 & 9.43 & 0.29 \\
$\mathrm{C} 1$ & Bot & 1.02 & 0.79 & 1.43 & 0.35 & 13.31 & 0.27 \\
$\mathrm{C} 2$ & Sur & 1.00 & 0.79 & 1.45 & 0.29 & 6.16 & 0.41 \\
$\mathrm{C} 2$ & Bot & 0.97 & 6.13 & 1.26 & 0.34 & 11.95 & 0.53 \\
E1 & Sur & 0.94 & 0.65 & 1.37 & 0.37 & 14.33 & 0.38 \\
E2 & Sur & 1.18 & 0.98 & 1.49 & 0.50 & 10.07 & 0.43 \\
E2 & Bot & 0.92 & 0.47 & 1.52 & 0.30 & 9.01 & 0.25 \\
E3 & Sur & 1.17 & 1.46 & 1.44 & 0.29 & 13.83 & 0.34 \\
E3 & Bot & 1.27 & 0.66 & 1.58 & 0.29 & 8.54 & 0.28 \\
Total average & 0.96 & 1.10 & 1.35 & 0.34 & 9.28 & 0.37 \\
\hline
\end{tabular}

\subsubsection{Ecological Risk Evaluation of Heavy Metal Pollution in} Sediments. Evaluation results of potential ecological risks of heavy metals in sediments in the surface layer of Jiuzhen Bay are shown in Table 10. Ranges of the ecological risk index $\left(E_{r}^{i}\right)$ for each heavy metal were $\mathrm{Cu}$ (0.54-10.66), $\mathrm{Zn}$ (0.17-2.43), As (2.44-5.91), Cd (3-25.97), Hg (5.8-139.5), and $\mathrm{Pb}(6.3-526.7)$, respectively. The $E_{r}^{i}$ values of $\mathrm{Cu}, \mathrm{Zn}, \mathrm{As}$, and $\mathrm{Cd}$ in sediments were less than 40 at all stations, representing a low degree of potential ecological risk. In contrast, the maximum $E_{r}^{i}$ value for $\mathrm{Pb}$ in sediments was 526.7 (station B1), which indicates a very serious potential
TABLE 7: Heavy metal contents and background values in sediments of Jiuzhen Bay $(\mu \mathrm{g} / \mathrm{g} d w)$.

\begin{tabular}{lccc}
\hline $\begin{array}{l}\text { Heavy metal } \\
\text { type }\end{array}$ & $\begin{array}{c}\text { Average value } \\
\text { (range) }\end{array}$ & $\begin{array}{c}\text { Background } \\
\text { value }\end{array}$ & Reference \\
\hline $\mathrm{Cu}$ & $8.6(1.1-21)$ & 9.8 & \\
$\mathrm{Zn}$ & $57(9-134)$ & 55 & {$[20]$} \\
$\mathrm{Cd}$ & $0.062(0.016-0.139)$ & 0.056 & \\
$\mathrm{~Pb}$ & $136(11-946)$ & 9 & \\
$\mathrm{As}$ & $6.3(3.7-8.9)$ & 15 & {$[34]$} \\
$\mathrm{Hg}$ & $0.028(0.004-0.087)$ & 0.025 & {$[35]$} \\
\hline
\end{tabular}

ecological risk. The $E_{r}^{i}$ values of $\mathrm{Pb}$ at all other stations were less than 40, representing a low degree of potential ecological risk. The $E_{r}^{i}$ values of $\mathrm{Hg}$ at three stations-A1, B3, and C2-were 83.8-139.5, indicating a relatively high degree of potential ecological risk. However, the $E_{r}^{i}$ values of $\mathrm{Hg}$ at all other stations were less than 40 , representing a low degree of potential ecological risk at other sites. According to the average $E_{r}^{i}$ values of heavy metals, potential ecological risks related to single heavy metals were ranked: $\mathrm{Pb}>\mathrm{Hg}>$ $\mathrm{Cd}>\mathrm{Cu}>\mathrm{As}>\mathrm{Zn}$.

The overall range of the potential ecological risk index (RI) was 18.9-556.1 in the study area, with a maximum value of 556.1 at station B1, indicating a relatively serious potential ecological risk. The $R I$ values of stations $\mathrm{A} 1$ and $\mathrm{B} 3$ were 222.4 and 166.7, respectively, indicating a moderate potential ecological risk. The $R I$ values of all other stations were less than 150, representing low to moderate potential ecological risks. According to average $R I$ values of all stations, potential ecological risks linked to sediments at each station were ranked: $\mathrm{B} 1>\mathrm{A} 1>\mathrm{B} 3>\mathrm{C} 2>\mathrm{B} 2>\mathrm{C} 1>\mathrm{E} 1>\mathrm{E} 3>\mathrm{E} 2$. 


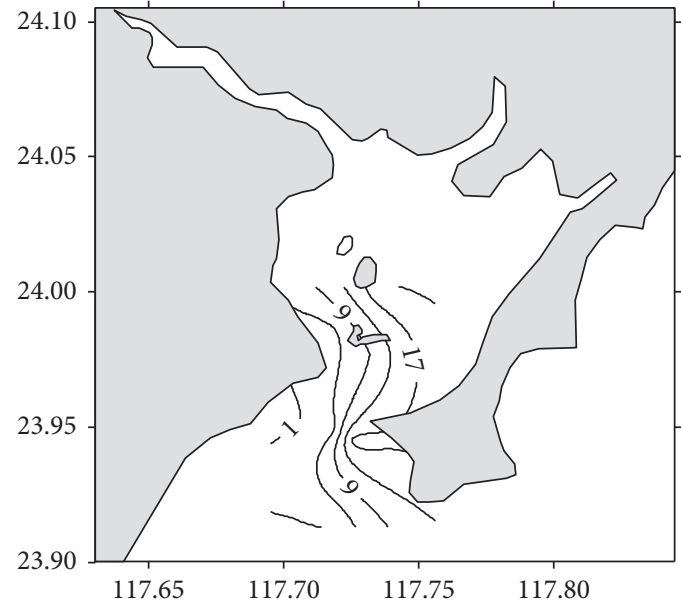

(a)

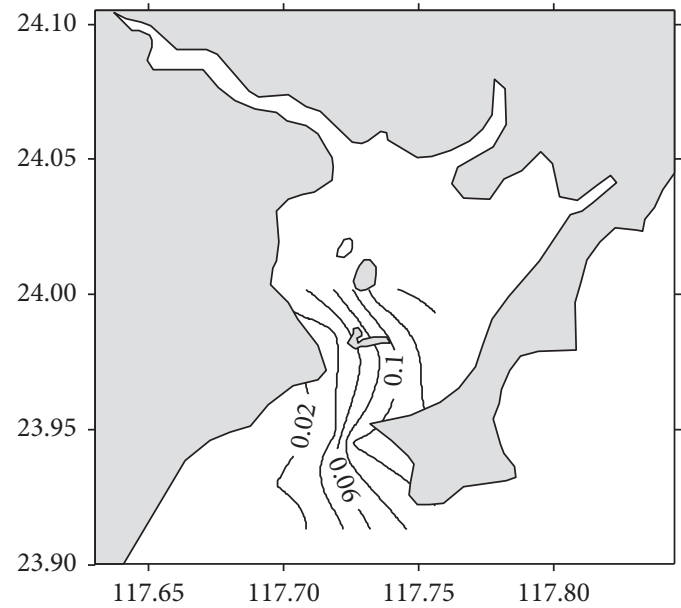

(c)

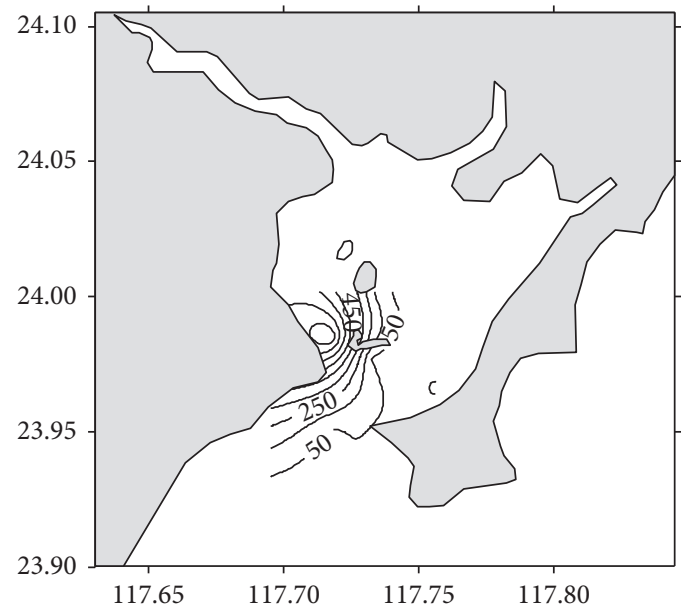

(e)

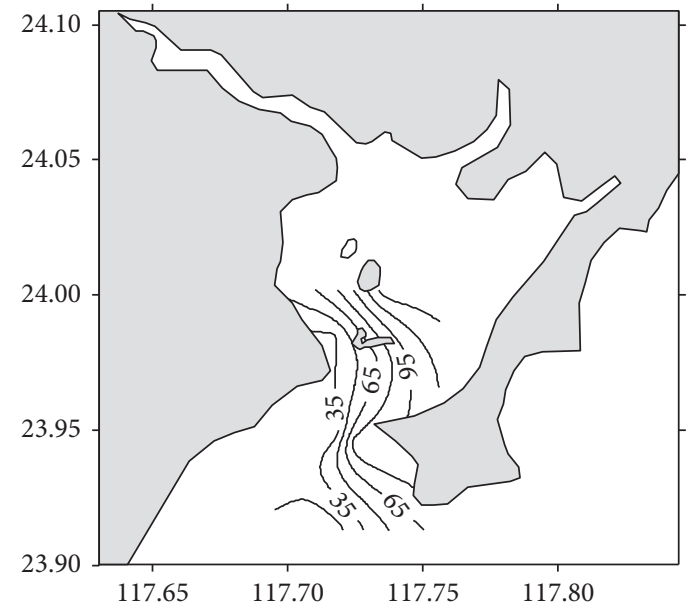

(b)

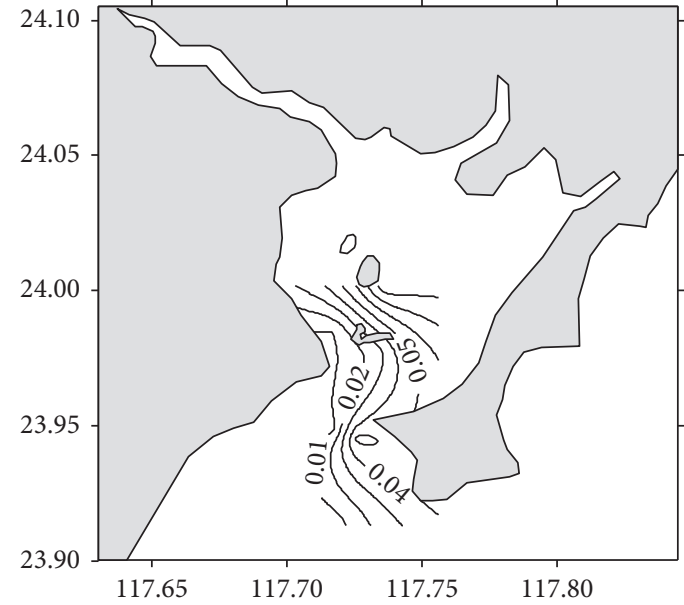

(d)

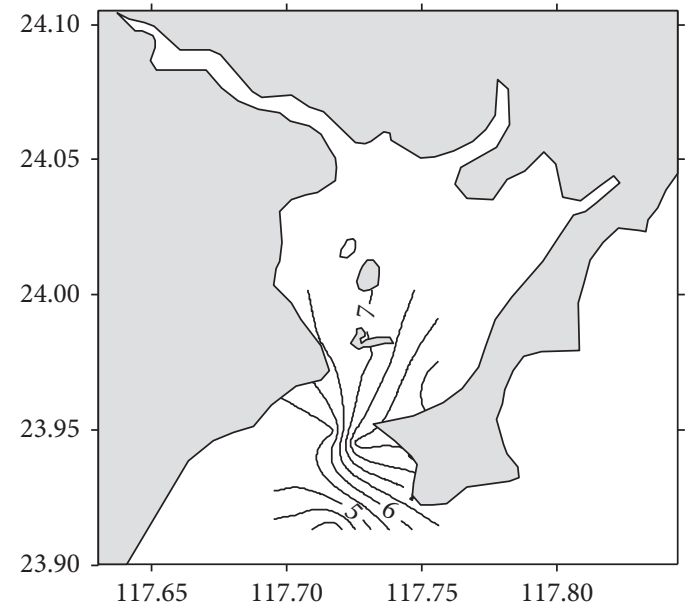

(f)

Figure 3: Distributions of various heavy metals in sediments of Jiuzhen Bay ( $\mu \mathrm{g} / \mathrm{g} \mathrm{dw}$ ): (a) Cu; (b) Zn; (c) Cd; (d) Hg; (e) Pb; (f) As. 
TABLE 8: Concentrations of heavy metals in sediments $(\mu \mathrm{g} / \mathrm{g} \mathrm{dw})$ in the present study compared to published data from other locations in China.

\begin{tabular}{lccccccc}
\hline Region & $\mathrm{Cu}$ & $\mathrm{Pb}$ & $\mathrm{Zn}$ & $\mathrm{Cd}$ & $\mathrm{Hg}$ & As & Reference \\
\hline Changjiang Subaqueous Delta & 26.79 & 26.55 & 94.34 & 0.09 & & & \\
Zhejiang-Fujian coastal & 33.98 & 37.69 & 129.26 & 0.08 & & & \\
Xiangshan Bay, China & 36.8 & 38.5 & 120.8 & 0.15 & 0.106 & 12.31 & {$[10]$} \\
Maowei Sea, China & 30.37 & 32.10 & 108.84 & 0.32 & 0.07 & 13.73 & {$[17]$} \\
Futou Bay, China & 3.54 & 14.2 & 25.8 & & 0.079 & 6.1 & {$[36]$} \\
Liaodong Bay, China & 19.66 & 22.64 & 70.2 & 0.22 & 0.056 & 9.28 & {$[37]$} \\
Data of history & 9.8 & 9 & 55 & 0.056 & & & \\
Jiuzhen Bay, China & 8.6 & 136 & 57 & 0.062 & 0.028 & 6.3 & This study \\
\hline
\end{tabular}

TABLE 9: Matrix of correlation coefficients among heavy metals and environmental factors in sediments of Jiuzhen Bay.

\begin{tabular}{|c|c|c|c|c|c|c|c|c|c|c|}
\hline & $\mathrm{Hg}$ & $\mathrm{Cu}$ & $\mathrm{Pb}$ & $\mathrm{Zn}$ & $\mathrm{Cd}$ & As & TOC & $\mathrm{TP}$ & $\mathrm{TN}$ & Eh \\
\hline $\mathrm{Hg}$ & 1 & & & & & & & & & \\
\hline $\mathrm{Cu}$ & $0.970^{\mathrm{a}}$ & 1 & & & & & & & & \\
\hline $\mathrm{Pb}$ & -0.151 & -0.158 & 1 & & & & & & & \\
\hline $\mathrm{Zn}$ & $0.978^{\mathrm{a}}$ & $0.983^{\mathrm{a}}$ & -0.129 & 1 & & & & & & \\
\hline $\mathrm{Cd}$ & $0.971^{\mathrm{a}}$ & $0.988^{\mathrm{a}}$ & -0.155 & $0.982^{\mathrm{a}}$ & 1 & & & & & \\
\hline As & $0.737^{\mathrm{b}}$ & $0.850^{\mathrm{a}}$ & 0.155 & $0.828^{\mathrm{a}}$ & $0.819^{\mathrm{a}}$ & 1 & & & & \\
\hline TOC & $0.883^{\mathrm{a}}$ & $0.921^{\mathrm{a}}$ & -0.163 & $0.909^{\mathrm{a}}$ & $0.941^{\mathrm{a}}$ & $0.814^{\mathrm{a}}$ & 1 & & & \\
\hline $\mathrm{TP}$ & $0.944^{\mathrm{a}}$ & $0.980^{\mathrm{a}}$ & -0.160 & $0.945^{\mathrm{a}}$ & $0.957^{\mathrm{a}}$ & $0.811^{\mathrm{a}}$ & $0.839^{\mathrm{a}}$ & 1 & & \\
\hline $\mathrm{TN}$ & $0.924^{\mathrm{a}}$ & $0.966^{\mathrm{a}}$ & -0.063 & $0.936^{\mathrm{a}}$ & $0.937^{\mathrm{a}}$ & $0.851^{\mathrm{a}}$ & $0.804^{\mathrm{a}}$ & $0.990^{\mathrm{a}}$ & 1 & \\
\hline Eh & $-0.877^{\mathrm{a}}$ & $-0.914^{\mathrm{a}}$ & 0.171 & $-0.944^{\mathrm{a}}$ & $-0.923^{\mathrm{a}}$ & $-0.858^{\mathrm{a}}$ & $-0.858^{\mathrm{a}}$ & $-0.863^{\mathrm{a}}$ & $-0.874^{\mathrm{a}}$ & 1 \\
\hline
\end{tabular}

${ }^{a}$ Correlation is significant at the 0.01 level. ${ }^{\mathrm{b}}$ Correlation is significant at the 0.05 level. TOC, total organic carbon; TN, total nitrogen; TP, total phosphorus; Eh, redox potential.

\subsection{Heavy Metal Contents in Living Organisms and Their Associated Ecological Risks}

3.3.1. Heavy Metal Content Characteristics in Living Organisms. Average heavy metal contents of representative living organisms from the study area are shown in Table 11. $\mathrm{Cu}, \mathrm{Zn}$, and $\mathrm{Cd}$ contents were highly variable in different kinds of living organisms. Average $\mathrm{Cu}$ and $\mathrm{Cd}$ contents in oysters were $73.19 \mu \mathrm{g} / \mathrm{g}$ ww and $0.748 \mu \mathrm{g} / \mathrm{g}$ ww, respectively; these values were much higher than those in fish $(0.23 \mu \mathrm{g} / \mathrm{g}$ ww and $0.001 \mu \mathrm{g} / \mathrm{g}$ ww). The $\mathrm{Zn}$ content was highest in oysters $(234 \mu \mathrm{g} / \mathrm{g} \mathrm{ww})$, followed by those in shrimps $(25.61 \mu \mathrm{g} / \mathrm{g} w \mathrm{w})$ and fish $(5.47 \mu \mathrm{g} / \mathrm{g} \mathrm{ww})$. The content of $\mathrm{Hg}$ was highest in fish $(0.043 \mu \mathrm{g} / \mathrm{g}$ ww $)$ and lowest in clams $(0.008 \mu \mathrm{g} / \mathrm{g} w \mathrm{w})$. The contents of $\mathrm{Pb}$ and As were highest in oysters, with average values of $0.361 \mu \mathrm{g} / \mathrm{g}$ ww and $3.14 \mu \mathrm{g} / \mathrm{g}$ ww, respectively. The lowest contents of $\mathrm{Pb}$ and As were detected in shrimps, with average values of $0.008 \mu \mathrm{g} / \mathrm{g} w \mathrm{w}$ and $1.16 \mu \mathrm{g} / \mathrm{g}$ ww, respectively.

Enrichment degrees of most heavy metals in shellfish were higher than those in fish, as reported by many previous researchers $[29,39,40]$. In this study, the contents of five heavy metals $(\mathrm{Cu}, \mathrm{Zn}, \mathrm{As}, \mathrm{Cd}$, and $\mathrm{Pb}$ ) in oysters were higher than those in all other living organisms. Two heavy metals ( $\mathrm{Cu}$ and $\mathrm{Zn}$ ) had high contents in shrimps, but these ranked second to their contents in oysters. The Hg contents in fish were higher than those in other living organisms.

\subsubsection{Ecological Risk Evaluation of Heavy Metal Pollution in} Living Organisms. Evaluation results of the single-factor pollution index $\left(P_{i}\right)$ and comprehensive pollution index $\left(P_{i j}\right)$ of heavy metals in living organisms are shown in Table 12. The evaluation index $\left(P_{i}\right)$ ranges of various heavy metals were $\mathrm{Cu}$ (0.01-7.32), $\mathrm{Zn}$ (0.14-11.70), As (0.15-3.14), Cd (0-3.74), $\mathrm{Hg}(0.08-0.50)$, and $\mathrm{Pb}(0.03-3.61)$. The singlefactor pollution index of heavy metals varied significantly in different species of living organisms. Although the heavy metal contents in fish and shrimps were all below the $\mathrm{Na}$ tional Quality Standards, those in mollusks greatly exceeded the standards. $\mathrm{Pb}$ and As contents in clams were above the threshold values of their standards, while all heavy metals (except $\mathrm{Hg}$ ) in oysters exceeded the standards. The ranking of the pollution indices of heavy metals in oysters was $\mathrm{Zn}>\mathrm{Cu}>\mathrm{Cd}>\mathrm{Pb}>\mathrm{As}>\mathrm{Hg}$.

The comprehensive pollution index $\left(P_{i j}\right)$ of heavy metals in living organisms ranged from 0.13 to 9.00 . Oysters displayed the highest comprehensive pollution index, being classified as heavily polluted. This was followed by clams, which were classified as lightly polluted. Heavy metal contents of fish and shrimps were not considered polluted.

3.3.3. Analysis of Enrichment of Different Heavy Metals in Living Organisms. According to the BCF and BSAF values of various organisms (Table 13), the rankings of enrichment coefficients of different heavy metals in seawater according to species were oysters: $\mathrm{Cu}>\mathrm{Zn}>\mathrm{Cd}>\mathrm{Pb}>\mathrm{As}>\mathrm{Hg}$, clams: $\mathrm{Pb}>\mathrm{Zn}>\mathrm{Cu}>\mathrm{Cd}>\mathrm{As}>\mathrm{Hg}$, fish: $\mathrm{Pb}>\mathrm{Zn}>\mathrm{Hg}>\mathrm{As}>\mathrm{Cu}>$ $\mathrm{Cd}$, and shrimps: $\mathrm{Cu}>\mathrm{Zn}>\mathrm{Pb}>\mathrm{As}>\mathrm{Hg}>\mathrm{Cd}$. Likewise, the rankings of enrichment coefficients of different heavy metals in the sediments according to species were oysters: $\mathrm{Cd}>\mathrm{Cu}>\mathrm{Zn}>\mathrm{Hg}>\mathrm{As}>\mathrm{Pb}$, clams: $\mathrm{Cd}>\mathrm{As}>\mathrm{Hg}>\mathrm{Zn}>$ $\mathrm{Cu}>\mathrm{Pb}$, fish: $\mathrm{Hg}>\mathrm{As}>\mathrm{Zn}>\mathrm{Cu}>\mathrm{Cd}>\mathrm{Pb}$, and shrimps: 
TABLE 10: The ecological risk index $\left(E_{r}^{i}\right)$ and potential ecological risk index $(R I)$ values for different heavy metals in sediments at all stations within Jiuzhen Bay.

\begin{tabular}{|c|c|c|c|c|c|c|c|}
\hline Station & $E_{\mathrm{Cu}}$ & $E_{\mathrm{Zn}}$ & $E_{\text {As }}$ & $E_{\mathrm{Cd}}$ & $E_{\mathrm{Hg}}$ & $E_{\mathrm{Pb}}$ & $R I$ \\
\hline $\mathrm{A} 1$ & 10.66 & 2.43 & 4.73 & 25.97 & 139.5 & 39.1 & 222.4 \\
\hline B1 & 1.84 & 0.61 & 4.48 & 6.19 & 16.3 & 526.7 & 556.1 \\
\hline B2 & 4.77 & 1.19 & 4.69 & 13.41 & 39.4 & 18.9 & 82.3 \\
\hline B3 & 9.61 & 2.01 & 5.91 & 24.28 & 91.5 & 33.4 & 166.7 \\
\hline $\mathrm{C} 1$ & 1.20 & 0.40 & 3.61 & 4.22 & 10.2 & 11.9 & 31.6 \\
\hline $\mathrm{C} 2$ & 9.23 & 1.71 & 5.44 & 19.22 & 83.8 & 27.4 & 146.8 \\
\hline E1 & 1.16 & 0.64 & 3.39 & 3.75 & 9.3 & 9.4 & 27.6 \\
\hline E2 & 0.68 & 0.17 & 3.00 & 3.00 & 5.8 & 6.3 & 18.9 \\
\hline E3 & 0.54 & 0.24 & 2.44 & 5.53 & 6.1 & 6.6 & 21.5 \\
\hline Average & 4.41 & 1.04 & 4.19 & 11.73 & 44.7 & 75.5 & 141.5 \\
\hline
\end{tabular}

TABLE 11: Heavy metal contents in various living organisms in Jiuzhen Bay ( $\mu \mathrm{g} / \mathrm{g} w w)$.

\begin{tabular}{lccccccc}
\hline Living organism & $\mathrm{Cu}$ & $\mathrm{Zn}$ & $\mathrm{As}$ & $\mathrm{Cd}$ & $\mathrm{Hg}$ & $\mathrm{Pb}$ & Reference \\
\hline Oyster & 73.19 & 234 & 3.14 & 0.748 & 0.025 & 0.361 & \\
Clam & 1.49 & 10.77 & 2.41 & 0.031 & 0.008 & 0.189 & Investigation data in this paper \\
Shrimp & 7.66 & 25.61 & 1.16 & 0.005 & 0.015 & 0.063 & \\
Fish & 0.23 & 5.47 & 2.40 & 0.001 & 0.043 & 0.097 & Marine biological quality (China) (GB18421-2001) \\
Bivalve mollusk & 10 & 0.1 & 1.0 & 0.2 & 0.05 & 0.1 & [24] \\
Shellfish & 100 & 2.0 & 8.0 & 2.0 & 0.20 & 2.0 & 2.0 \\
Fish & 20 & 2.0 & 5.0 & 0.6 & 0.30 & 2.0 & \\
\hline
\end{tabular}

TABLE 12: Values of the pollution index $\left(P_{i}\right)$ and comprehensive pollution index $\left(P_{i j}\right)$ for single-factor heavy metal pollution in various living organisms.

\begin{tabular}{lccccccc}
\hline Living organism & $P_{\mathrm{Cu}}$ & $P_{\mathrm{Zn}}$ & $P_{\mathrm{As}}$ & $P_{\mathrm{Cd}}$ & $P_{\mathrm{Hg}}$ & $P_{\mathrm{Pb}}$ & Ave $P_{i}$ \\
\hline Oyster & 7.32 & 11.70 & 3.14 & 3.74 & 0.50 & 3.61 & 5.00 \\
Clam & 0.15 & 0.54 & 2.41 & 0.16 & 0.16 & 1.89 & 0.88 \\
Fish & 0.01 & 0.14 & 0.48 & - & 0.14 & 0.05 & 0.14 \\
Shrimp & 0.08 & 0.17 & 0.15 & - & 0.08 & 0.03 & 0.08 \\
Average value & 1.89 & 3.14 & 1.54 & 0.97 & 0.22 & 1.40 & 0.35 \\
\hline
\end{tabular}

TABLE 13: Bioconcentration factors (BCFs) and biota-sediment accumulation factors (BSAFs) of various living organisms.

\begin{tabular}{|c|c|c|c|c|c|c|c|}
\hline Factor & Living organism & $\mathrm{Cu}$ & $\mathrm{Zn}$ & As & $\mathrm{Cd}$ & $\mathrm{Hg}$ & $\mathrm{Pb}$ \\
\hline \multirow{4}{*}{ BCF } & Oyster & 15185 & 10636 & 116 & 2200 & 54 & 976 \\
\hline & Clam & 309 & 490 & 89 & 91 & 17 & 511 \\
\hline & Fish & 48 & 249 & 89 & 3 & 93 & 262 \\
\hline & Shrimp & 1589 & 1164 & 43 & 15 & 33 & 170 \\
\hline \multirow{4}{*}{ BSAF } & Oyster & 8.47 & 4.08 & 0.50 & 12 & 0.90 & \multirow{4}{*}{$<0.01$} \\
\hline & Clam & 0.17 & 0.19 & 0.38 & 0.50 & 0.29 & \\
\hline & Fish & 0.03 & 0.10 & 0.38 & 0.02 & 1.54 & \\
\hline & Shrimp & 0.89 & 0.45 & 0.18 & 0.08 & 0.54 & \\
\hline
\end{tabular}

$\mathrm{Cu}>\mathrm{Hg}>\mathrm{Zn}>\mathrm{As}>\mathrm{Cd}>\mathrm{Pb}$. The ranking of heavy metal contents in living organisms was not consistent with that of seawater or sediments. This indicates that, at low concentrations, the enrichment of heavy metals is not only related to the concentrations of heavy metals in seawater and sediments but also to many other factors.

In oysters, clams, and shrimps, the enrichment coefficients of $\mathrm{Cu}, \mathrm{Zn}, \mathrm{Cd}$, and $\mathrm{Pb}$ were higher than those of $\mathrm{As}$ and $\mathrm{Hg}$. This is because $\mathrm{Cu}$ and $\mathrm{Zn}$ are essential elements of life; thus, they are actively absorbed by living organisms. Therefore, the ability of marine organisms to be enriched in $\mathrm{Cu}$ and $\mathrm{Zn}$ was much higher than for nonessential metal elements [41]. Notably, the excretion of $\mathrm{Pb}$ and $\mathrm{Cd}$ is very slow in most organisms. Because shellfish are filter feeders, and both $\mathrm{Pb}$ and $\mathrm{Cd}$ complexes in suspension and in the sediments were ingested by and enriched in shellfish [42], accounting for the high enrichment coefficients of $\mathrm{Pb}$ and $\mathrm{Cd}$ in oysters, clams, and shrimps.

According to Table 13, the enrichment coefficient of $\mathrm{Hg}$ was higher in fish than in shellfish. This is caused by the higher capacity of fish to absorb $\mathrm{Hg}$ through water and food intake, as well as physiological mechanisms that produce $\mathrm{Hg}$ enrichment within their bodies [43].

Studies have suggested that an enrichment coefficient greater than 1000 indicates a potential cumulative problem [25]. In the present study, an enrichment coefficient greater 
than 1000 was found for $\mathrm{Cu}, \mathrm{Zn}$, and $\mathrm{Cd}$ in oysters and $\mathrm{Cu}$ and $\mathrm{Zn}$ in shrimps, indicating serious accumulation of $\mathrm{Cu}$, $\mathrm{Zn}$, and Cd by oysters and shrimps in Jiuzhen Bay. Although the enrichment coefficients of $\mathrm{Pb}, \mathrm{Hg}$, and $\mathrm{As}$ were lower than 1000, the pollution levels of $\mathrm{Pb}, \mathrm{Hg}$, and As in seawater and sediments were relatively high. Therefore, the ecological and human health risks related to $\mathrm{Pb}, \mathrm{Hg}$, and $\mathrm{As}$ in the marine organisms of Jiuzhen Bay cannot be neglected.

\section{Conclusions}

This study reported the contents, distributions, pollution levels, and ecological risks of heavy metals $(\mathrm{Cu}, \mathrm{Pb}, \mathrm{Zn}, \mathrm{Cd}$, $\mathrm{Hg}$, and $\mathrm{As}$ ) in seawater, sediments, and living organisms of Jiuzhen Bay. The seawater was mainly polluted by $\mathrm{Hg}$ and As, while heavy $\mathrm{Pb}$ and $\mathrm{Hg}$ pollution was detected in sediments at a few stations. The main sources of heavy metal pollution in the marine environments of Jiuzhen Bay are from surface runoff carried by the Luxi and Wujiang Rivers and coastal discharges from local industries. The enrichment coefficients of $\mathrm{Cu}, \mathrm{Zn}$, and $\mathrm{Cd}$ were high in oysters and clams. According to the comprehensive pollution index values, the heavy metal pollution in oysters and clams was classified as heavy and light pollution, respectively. The heavy metal contents in fish and shrimps did not reach polluted levels. Given the pollution of $\mathrm{Pb}, \mathrm{Hg}$, and $\mathrm{As}$ in seawater and sediments at some stations within Jiuzhen Bay, the potential risks of $\mathrm{Pb}, \mathrm{Hg}$, and As in living organisms to both the local ecology and human health deserve increased attention. To ensure the safety of aquaculture products in Jiuzhen Bay, the sources of heavy metal pollution should be strictly controlled, and the polluted areas should be treated to restore their ecological functions.

\section{Data Availability}

No data were used to support this study.

\section{Disclosure}

Xia Sun and Bao-Shi Li are the co-first authors.

\section{Conflicts of Interest}

The authors declare that they have no conflicts of interest.

\section{Authors' Contributions}

Xia Sun and Bao-Shi Li contributed equally.

\section{Acknowledgments}

This work was financially supported by the National Natural Science Foundation of China (Grant no. 41676074), the National Key Research and Development Program of China (no. 2018YFC140707600), and the Basic Scientific Fund for the National Public Research Institutes of China (Grant no. 2016Q04).

\section{References}

[1] P. Zhang, C. J. Jin, Z. F. Sun, G. H. Huang, and Z. L. She, "Assessment of acid enhancement schemes for electrokinetic remediation of $\mathrm{Cd} / \mathrm{Pb}$ contaminated soil," Water Air and Soil Pollution, vol. 227, no. 6, p. 217, 2016.

[2] G. Hu, S. P. Bi, G. Xu, Y. Zhang, X. Mei, and A. C. Li, "Distribution and assessment of heavy metals off the Changjiang River mouth and adjacent area during the past century and the relationship of the heavy metals with anthropogenic activity," Marine Pollution Bulletin, vol. 96, no. 12, pp. 434-440, 2015.

[3] J. Lu, A. Li, and P. Huang, "Distribution, sources and contamination assessment of heavy metals in surface sediments of the South Yellow Sea and northern part of the East China Sea," Marine Pollution Bulletin, vol. 124, no. 1, pp. 470-479, 2017.

[4] L. Zhang, Z. Shi, J. Zhang, Z. Jiang, F. Wang, and X. Huang, "Spatial and seasonal characteristics of dissolved heavy metals in the east and west Guangdong coastal waters, South China," Marine Pollution Bulletin, vol. 95, no. 1, pp. 419-426, 2015.

[5] S. Yin, Y. Wu, W. Xu, Y. Li, Z. Shen, and C. Feng, "Contribution of the upper river, the estuarine region, and the adjacent sea to the heavy metal pollution in the Yangtze Estuary," Chemosphere, vol. 155, pp. 564-572, 2016.

[6] Q. Rao, Z. Sun, L. Tian, J. Li, W. Sun, and W. Sun, "Assessment of arsenic and heavy metal pollution and ecological risk in inshore sediments of the Yellow River Estuary, China," Stochastic Environmental Research and Risk Assessment, vol. 32, no. 10, pp. 2889-2902, 2018.

[7] Q. Cao, H. Wang, Y. Li et al., "The national distribution pattern and factors affecting heavy metals in sediments of water systems in China," Soil and Sediment Contamination: An International Journal, vol. 27, no. 2, pp. 79-97, 2018.

[8] Z. Sun, J. Li, T. He et al., "Spatial variation and toxicity assessment for heavy metals in sediments of intertidal zone in a typical subtropical estuary (Min River) of China," Environmental Science and Pollution Research, vol. 24, no. 29, pp. 23080-23095, 2017.

[9] J. Liang, J. Liu, G. Xu, and B. Chen, "Distribution and transport of heavy metals in surface sediments of the Zhejiang nearshore area, East China Sea: sedimentary environmental effects," Marine Pollution Bulletin, vol. 146, pp. 542-551, 2019.

[10] C. Wang, X. Zou, Z. Feng, Z. Hao, and J. Gao, "Distribution and transport of heavy metals in estuarine-inner shelf regions of the East China Sea," Science of the Total Environment, vol. 644, pp. 298-305, 2018.

[11] Y.-M. Chen, J.-b. Gao, Y.-Q. Yuan, J. Ma, and S. Yu, "Relationship between heavy metal contents and clay mineral properties in surface sediments: implications for metal pollution assessment," Continental Shelf Research, vol. 124, pp. 125-133, 2016.

[12] Y. N. Zhang, Q. He, J. M. Chen, C. Lin, and W. D. Ji, "Heavy metals process in water and pollution risk assessment in surface sediments of the ZhuJiang river estuary," Acta Oceanologica Sinica, vol. 35, no. 2, pp. 178-186, 2013, in Chinese.

[13] M. F. Yang, S. H. Zheng, Y. Y. Xi, and S. L. Zhong, "The horizontal distribution and affecting factors of dissolved heavy metals in seawater of DongShan bay, fujian Province of China," Journal of Marine Sciences, vol. 34, no. 2, pp. 75-82, 2016.

[14] M. M. Mazrouh and M. H. Mourad, "Biochemical composition and bioaccumulation of heavy metals in some seafood in the mediterranean coast of Egypt," Egyptian Journal of Aquatic Biology and Fisheries, vol. 23, no. 1, pp. 381-390, 2019. 
[15] M. K. Ahmed, M. A. Baki, M. S. Islam et al., "Human health risk assessment of heavy metals in tropical fish and shellfish collected from the river Buriganga, Bangladesh," Environmental Science and Pollution Research, vol. 22, no. 20, pp. 15880-15890, 2015.

[16] S. Satapathy and C. R. Panda, "Toxic metal ion in seafood: meta-analysis of human carcinogenic and non-carcinogenic threat assessment, a geomedical study from Dhamra and Puri, Odisha," Human and Ecological Risk Assessment: An International Journal, vol. 23, no. 4, pp. 864-878, 2017.

[17] B. Zhao, X. Wang, H. Jin et al., "Spatiotemporal variation and potential risks of seven heavy metals in seawater, sediment, and seafood in Xiangshan Bay, China (2011-2016)," Chemosphere, vol. 212, pp. 1163-1171, 2018.

[18] R. Zhao, S. Yan, M. Liu et al., "Seafood consumption among Chinese coastal residents and health risk assessment of heavy metals in seafood," Environmental Science and Pollution Research, vol. 23, no. 16, pp. 16834-16844, 2016.

[19] J. L. Cheng, Y. N. Ma, T. T. Liu, and Q. Zhuo, "Accumulation and health risks of heavy metals in the seafood from China," Journal of Hygiene Research, vol. 46, no. 1, pp. 148-154, 2017.

[20] F. Chen, Gulf Chronicles of China-Eighth Fascicle, China Ocean Press, Beijing, China, 1993.

[21] L. Hakanson, "An ecological risk index for aquatic pollution control.a sedimentological approach," Water Research, vol. 14 , no. 8, pp. 975-1001, 1980.

[22] W. X. Liu, Z. K. Luan, and H. X. Tang, "Environmental assessment on heavy metal pollution in the sediments of le an river with potential ecological risk index," Acta Ecologica Sinica, vol. 19, no. 2, pp. 206-211, 1999.

[23] N. X. Zhang, C. H. Cao, R. Z. Ren et al., "Heavy metals in the surface sediment of the dumping ground outside Jiaozhou bay and their potential ecological risk," Environmental Science, vol. 32, no. 5, pp. 1315-1320, 2011.

[24] W. D. Ji, Monitoring and Evaluation Methods of Heavy Metal Pollution Elements in Offshore, pp. 196-197, China Ocean Press, Beijing, China, 2015.

[25] N. Sun, W. X. Huang, and H. B. Yu, “Analysis and assessment of heavy metals accumulation feature of sediments and marine organisms from Zhanjiang Harbor," Marine Environmental Science, vol. 34, no. 5, pp. 669-672, 2015.

[26] M. Soto-Jiménez, F. Páez-Osuna, and F. Morales-Hernández, "Selected trace metals in oysters (Crassostrea iridescens) and sediments from the discharge zone of the submarine sewage outfall in Mazatlán Bay (southeast Gulf of California): chemical fractions and bioaccumulation factors," Environmental Pollution, vol. 114, no. 3, pp. 357-370, 2001.

[27] Y. H. Xu, R. Q. Liao, J. Su, and L. B. Gong, "The content and pollution evaluation of six heavy metals in surface water and plankton in the eastern area of Qinzhou bay," Oceanologia et Limnologia Sinica, vol. 48, no. 5, pp. 960-969, 2017.

[28] S. X. LI, S. q Wei, J. L. Lin, and D. B. Wang, "Pollution evaluation of heavy metals in sea water and surface sediments in maowei sea," Journal of Jianghan University (Natural Science Edition), vol. 43, no. 5, pp. 471-476, 2015.

[29] Z. Zeng, C. L. Chen, S. Ke, Z. K. Zhao, and Q. Xie, "The characteristic and evaluation of heavy metal pollution in seawater and organisms of the Bohe Bay," Ocean Development And Management, vol. 8, pp. 24-28, 2019.

[30] T. T. Li, L. Wei, Y. L. Lv et al., "On distribution and pollution of heavy metals in water environment of Jiaozhou bay in Yellow sea," Journal of Southwest China Normal University (Natural Science Edition), vol. 41, no. 6, pp. 60-66, 2016.
[31] X. L. Zhang, H. T. Chen, Q. Z. Yao, and X. X. Zhang, "The seasonal changes and flux of trace elements in the lower reaches of Yellow River," Periodical of Ocean University of China, vol. 43, no. 8, pp. 69-75, 2013.

[32] Y. Che, Q. He, and W.-Q. Lin, "The distributions of particulate heavy metals and its indication to the transfer of sediments in the Changjiang Estuary and Hangzhou Bay, China," Marine Pollution Bulletin, vol. 46, no. 1, pp. 123-131, 2003.

[33] R. P. Gambrell, J. B. Wiesepape, W. H. Patrick Jr., and M. C. Duff, "The effects of $\mathrm{pH}$, redox, and salinity on metal release from a contaminated sediment," Water, Air, and Soil Pollution, vol. 57-58, no. 1, pp. 359-367, 1991.

[34] L. X. Zhang, S. Ren, and J. Cai, "Enrichment of heavy metals in the surface sediments from the three regions of random dumping in east China sea and assessment of their potential ecological risk," Marine Science Bulletin, vol. 24, no. 2, pp. 92-96, 2005.

[35] F. X. Guo, S. H. Lv, D. Q. Teng, T. Jiang, and Z. P. Jiao, "Distribution patterns and evaluation on potential ecological risk of heavy metals in surface sediments of the Yellow sea," Journal of Anhui Agricultural Sciences, vol. 39, no. 15, pp. 9212-9216, 2011.

[36] S. T. Chen, W. L. Wang, and Q. S. Li, "Assessment of environmental quality in seawater and sediment of Futou bay, fujia," Environment and Sustainable Development, vol. 3, pp. 156-158, 2017.

[37] J. Wang, S. Y. Ye, E. A. Laws, H. M. Yuan, X. G. Ding, and G. M. Zhao, "Surface sediment properties and heavy metal pollution assessment in the Shallow Sea Wetland of the Liaodong Bay, China," Marine Pollution Bulletin, vol. 120, no. 1-2, pp. 347-354, 2017.

[38] P. Zhang, G. Huang, C. An et al., "An integrated gravitydriven ecological bed for wastewater treatment in subtropical regions: Process design, performance analysis, and greenhouse gas emissions assessment," Journal of Cleaner Production, vol. 212, pp. 1143-1153, 2019.

[39] P. Bustamante, F. Caurant, S. W. Fowler, and P. Miramand, "Cephalopods as a vector for the transfer of cadmium to top marine predators in the north-east Atlantic ocean," Science of the Total Environment, vol. 220, no. 1, pp. 71-80, 1998.

[40] M. Cheggour, A. Chafik, N. S. Fisher, and S. Benbrahim, "Metal concentrations in sediments and clams in four Moroccan estuaries," Marine Environmental Research, vol. 59, no. 2, pp. 119-137, 2005.

[41] X. J. Zhang, S. Zhao, C. H. Feng, and H. R. Wang, "Distribution and accumulation factors of heavy metals in organisms in southern Bohai Bay," Journal of Dalian Ocean University, vol. 29, no. 3, pp. 267-271, 2014.

[42] W. P. Sun, J. M. Pan, X. Y. Liu, Y. X. Huang, and M. H. Zheng, "Study of the content of heavy metals in the mollusks from the near-shore of Zhejiang Province," Journal of Marine Sciences, vol. 28, no. 4, pp. 43-49, 2010.

[43] W. P. Sun, X. Y. Liu, J. M. Pan, and H. X. Weng, "Levels of heavy metals in commercial fish species from the near-shore of Zhejiang Province," Journal of Zhejiang University (Science Edition), vol. 39, no. 3, pp. 338-344, 2012. 